\title{
Editorial \\ Changing Quaternary Environment in the Mediterranean
}

\author{
Maša Surić ${ }^{1, *(1)}$ and Lara Wacha ${ }^{2} \mathbb{D}$ \\ 1 Department of Geography, University of Zadar, 23000 Zadar, Croatia \\ 2 Department of Geology, Croatian Geological Survey, 10000 Zagreb, Croatia; lwacha@hgi-cgs.hr \\ * Correspondence: msuric@unizd.hr
}

check for

updates

Citation: Surić, M.; Wacha, L.

Changing Quaternary Environment in the Mediterranean. Geosciences 2022, 12, 61. https://doi.org/ 10.3390/geosciences12020061

Received: 26 January 2022

Accepted: 27 January 2022

Published: 29 January 2022

Publisher's Note: MDPI stays neutral with regard to jurisdictional claims in published maps and institutional affiliations.

Copyright: (C) 2022 by the authors. Licensee MDPI, Basel, Switzerland. This article is an open access article distributed under the terms and conditions of the Creative Commons Attribution (CC BY) license (https:// creativecommons.org/licenses/by/ $4.0 /)$.
Reconstruction of the Quaternary environment is one of the main issues in the global endeavour of predicting future changes, to which the Mediterranean Sea is highly sensitive due to its latitude and landlocked position. Along with ubiquitous traditional methods and techniques, novel multidisciplinary and sophisticated approaches have been utilized to examine overall natural and anthropogenic changes and their temporal and spatial dimensions. The proxy records of landscape transformation can be found in different archives and forms: geomorphic features, biological remains, loess, speleothem and tufa sequences, paleosol, pollen, and geochemical imprints in lake and marine deposits etc., complemented with archaeological and even historical records. However, their correlations produce the most valuable platform for future predictions.

This Special Issue of Geosciences encompasses seven different methodologies of reconstructing ever-changing inland, coastal, and submerged Mediterranean landscapes in the course of the Quaternary. The first paper, authored by Antonioli et al. [1], is a thorough review of one of the major climate-driven environmental changes that have repeatedly transformed the Mediterranean landscape: the sea-level change. Their reconstructions are based on speleothems from submerged karst caves. Namely, submerged speleothems are irrefutable evidence of former lower sea levels, since their growth is possible only in subaerial conditions, while the growth hiatuses of submerged phases from transgressive episodes may be marked by marine biogenic overgrowth (encrustations). However, along with global eustatic sea-level changes, accurate reconstruction of the relative sea-level changes must take into consideration response to regional glacial and hydro-isostatic adjustment. Comprehensive overview of radiometrically $\left({ }^{14} \mathrm{C}, \mathrm{U}-\mathrm{Th}\right)$ dated submerged speleothem samples from 32 locations covers the last 1.4 Myr, but the main focus is on the period from Marine Isotope Stages (MIS) 7.5 to MIS 1, employing different ice sheet models to estimate the contribution of ice-loading-induced crustal and geoidal deformations.

As an archive of valuable paleoclimate proxy records, speleothems were also examined by Surić et al. [2], presenting stable carbon and oxygen isotope records of the hydroclimate variability throughout the last glacial cycle from the Manita peć Cave (Velebit Mountain, Croatia). U-Th dated speleothem records, covering the paleoclimate history of this coastal mountain, range from MIS 5 to MIS 3, and the transition from MIS 2 to MIS 1. Presumably, the transformation of this littoral site to a continental one, due to the lower sea-level stands, with somewhat higher amounts of orographic precipitation, was a site-specific effect that masked regional environmental changes.

The paper by Barešić et al. [3] also presents Croatian karst features, but here the tufa deposits from the Zrmanja River Canyon were discussed as a potential tool for paleoenvironmental research. Radiocarbon ages of organic/human and carbonate fraction from modern tufa at the riverbed to the $\sim 40$ ka-old samples $20 \mathrm{~m}$ above the present river course, along with their stable oxygen and carbon isotope composition, enabled the partial reconstruction of the landscape evolution, back to MIS 3. The authors confirmed previous presumptions of a significantly different paleo-Zrmanja River course and the development of its present riverbed after $40 \mathrm{ka} B P$, having the major incision period between 25,000 and $6000 \mathrm{cal} \mathrm{BP}$ with an estimated incision rate of $1.1 \mathrm{~mm} / \mathrm{yr}$. 
The incision of the Ofanto River (Apulia, Italy) and its palaeogeography from MIS 2 on the Manfredonia Gulf (South Adriatic Sea) is presented by De Santis et al. [4]. The transgressive architecture of coastal barrier systems in the Ofanto incised valley and surrounding shelf was derived from seismic profiles, in which the authors identified two sea-level rise slowstands interrupted with meltwater pulses (MWP) MWP-1A and MWP-1B. Slowstands enabled the formation of two barrier-shoreface/estuarine-backbarrier systems, while the MWPs led to rollover and overstepping of the barrier systems, as a response to late Pleistocene-Holocene stepped sea-level rise.

A paleogeographic reconstruction of the Akrotiri Salt Lake (Lemesos, Cyprus) was presented by Polidorou et al. [5], based on detailed sedimentological, micropaleontological and geochemical analyses of sediment cores, supported by ${ }^{14} \mathrm{C}$ dating of mollusc shells. They showed that the Salt Lake developed in three phases, from an open bay (6000 to 4000 years BP) to a semi closed lagoon (4000 to 2000 years BP), and finally to a restricted lagoon (2000 years to the present day) significantly influenced by the sea, either by direct connection, high energy events (storms) and/or anthropogenic activity.

The dune fields surrounding the Akrotiri Salt Lake were investigated by Polidorou and Evelpidou [6]. Based on geomorphic observations, sedimentological data and OSL dating, the development of the western dune field started $\sim 56 \mathrm{ka}$ ago, when the relative sea level was significantly lower and contributed to the development of the western tombolo. The eastern dune field developed in the late Holocene, after the formation of the eastern spit, which resulted in the formation of the Akrotiri Salt Lake.

Finally, the research conducted by Faričić and Juran [7] leads us to the most recent times, the Anthropocene, with significant traces of human activity left in the natural environment. The authors investigated lime production on the Croatian islands (NE Adriatic Sea) with imprints left by anthropogenic forms in insular karst and degraded Mediterranean vegetation. Apart from the field observation, detailed toponomastic analyses, complemented with archival and cartographic sources dating back to the 16th c., depict interconnections between the human-shaped natural environment and the linguistic landscape.

Author Contributions: Conceptualization and writing, M.S. and L.W. All authors have read and agreed to the published version of the manuscript.

Funding: Guest Editors received no external funding for this Special Issue editing.

Acknowledgments: Geosciences in-house editors are gratefully acknowledged for the cooperation and support during the manuscript processing. We also thank all the authors for the interesting contributions and reviewers for their efforts in improving final research presentation.

Conflicts of Interest: The authors declare no conflict of interest.

\section{References}

1. Antonioli, F.; Furlani, S.; Montagna, P.; Stocchi, P. The Use of Submerged Speleothems for Sea Level Studies in the Mediterranean Sea: A New Perspective Using Glacial Isostatic Adjustment (GIA). Geosciences 2021, 11, 77. [CrossRef]

2. Surić, M.; Bajo, P.; Lončarić, R.; Lončar, N.; Drysdale, R.N.; Hellstrom, J.C.; Hua, Q. Speleothem Records of the Hydroclimate Variability throughout the Last Glacial Cycle from Manita peć Cave (Velebit Mountain, Croatia). Geosciences 2021, $11,347$. [CrossRef]

3. Barešić, J.; Faivre, S.; Sironić, A.; Borković, D.; Lovrenčić Mikelić, I.; Drysdale, R.N.; Krajcar Bronić, I. The Potential of Tufa as a Tool for Paleoenvironmental Research-A Study of Tufa from the Zrmanja River Canyon, Croatia. Geosciences 2021, 11, 376. [CrossRef]

4. De Santis, V.; Caldara, M.; Pennetta, L. Transgressive Architecture of Coastal Barrier Systems in the Ofanto Incised Valley and Its Surrounding Shelf in Response to Stepped Sea-Level Rise. Geosciences 2020, 10, 497. [CrossRef]

5. Polidorou, M.; Evelpidou, N.; Tsourou, T.; Drinia, H.; Salomon, F.; Blue, L. Observations on Palaeogeographical Evolution of Akrotiri Salt Lake, Lemesos, Cyprus. Geosciences 2021, 11, 321. [CrossRef]

6. Polidorou, M.; Evelpidou, N. Geomorphology of the Coastal Sand Dune Fields and Their Association with the Palaeolandscape Evolution of Akrotiri Peninsula, Lemesos, Cyprus. Geosciences 2021, 11, 448. [CrossRef]

7. Faričić, J.; Juran, K. Human Footprints in the Karst Landscape: The Influence of Lime Production on the Landscape of the Northern Dalmatian Islands (Croatia). Geosciences 2021, 11, 303. [CrossRef] 